
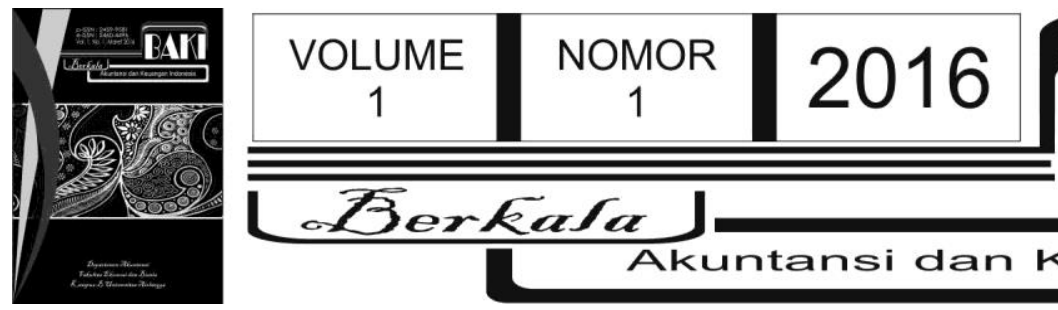

Berkata

Akuntansi dan Keuangan Indonesia

\title{
Persepsi Calon Wajib Pajak Dan Wajib Pajak Terhadap Etika Penggelapan Pajak Di Salatiga
}

\author{
Nelphy Bryan Abrahams, Ari Budi Kristanto* \\ *Universitas Kristen Satya Wacana \\ *ari.kristanto@staff.uksw.edu
}

\begin{tabular}{|c|c|}
\hline INFOARTIKEL & ABSTRAK \\
\hline $\begin{array}{l}\text { Histori Artikel: } \\
\text { Tanggal Masuk } 5 \text { Oktober } 2015 \\
\text { Tanggal Diterima } 8 \text { Maret } 2016 \\
\text { Tersedia Online } 31 \text { Maret } 2016 \\
\text { Kata Kunci: } \\
\text { Penggelapan Pajak; } \\
\text { Wajib Pajak; } \\
\text { Calon Wajib Pajak; } \\
\text { Etika }\end{array}$ & $\begin{array}{l}\text { Sejumlah wajib pajak sampai saat ini masih melakukan penggelapan } \\
\text { pajak. Hal tersebut dilakukan dengan alasan antara lain } \\
\text { ketidakpuasan terhadap sistem perpajakan, praktik perpajakan yang } \\
\text { tidak adil dan perlakuan diskriminasi perpajakan. Penelitian ini } \\
\text { dilakukan untuk mengeksplorasi persepsi wajib pajak dan calon wajib } \\
\text { pajak terhadap perilaku penggelapan pajak, secara khusus dari sudut } \\
\text { pandang sistem perpajakan, keadilan pajak dan diskriminasi dalam } \\
\text { perpajakan. Penelitian ini menggunakan metoda survey pada } \\
\text { responden. Responden wajib pajak dalam penelitian ini wajib pajak } \\
\text { orang pribadi dengan penghasilan dari pekerjaan dan usaha. Adapun } \\
\text { calon wajib pajak diperoleh dari mahasiswa program studi } \\
\text { manajemen dan akuntansi. Data penelitian selanjutnya dianalisis } \\
\text { dengan menggunakan teknik analisis statistik deskriptif. Hasil } \\
\text { penelitian ini menemukan bahwa pada umumnya responden tidak } \\
\text { menyetujui bahwa penggelapan pajak merupakan tindakan yang etis, } \\
\text { meskipun sistem perpajakan tidak berjalan dengan baik, tidak ada } \\
\text { keadilan dan terjadi diskriminasi dalam praktik perpajakan. } \\
\text { Berdasarkan temuan penelitian ini, dapat diperoleh simpulan bahwa } \\
\text { secara umum wajib pajak dan calon wajib pajak persepsi negatif } \\
\text { terhadap penggelapan pajak. Hal ini menjadi modal bagi pemerintah } \\
\text { dalam meningkatkan kepatuhan pajak. }\end{array}$ \\
\hline
\end{tabular}

\section{Pendahuluan}

Penerimaan pajak adalah komponen penting dalam anggaran negara. Menurut Direktorat Jendral Pajak (2014), pendapatan negara berdasarkan APBN tahun 2013 terdiri dari pajak dalam negeri Rp 1.099,94 Triliun (73,23\%), sumber daya alam (SDA) Rp 203,73 Triliun (13,56\%) dan pajak perdagangan internasional Rp 48,42 Triliun (3,22\%). Sedangkan penerimaan bukan pajak (selain SDA) sebesar Rp 149,92 Triliun (9,98\%). Dari data tersebut, tampak bahwa pendapatan negara terbesar berasal dari pajak dalam negeri. Melihat fakta mengenai struktur penerimaan negara tersebut, maka penerimaan pajak perlu dijaga keberlanjutannya bahkan ditingkatkan.

Sektor pajak yang merupakan komponen utama penerimaan negara ternyata belum mencapai target. Beberapa tahun belakangan ini penerimaan pajak oleh Direktorat Jendral Pajak (DJP) tidak 
sesuai target yang ditetapkan. Data target dan realisasi penerimaan pajak dari tahun 2011 hingga 2013 ditampikan dalam tabel 1 sebagai berikut.

Tabel 1

Target dan Realisasi Penerimaan Pajak

\begin{tabular}{|l|l|l|}
\hline Tahun & Target & Realisasi \\
\hline 2011 & 878 triliun & 872 triliun \\
\hline 2012 & 900 triliun & 835 triliun \\
\hline 2013 & $1.148,4$ triliun & $1.071,1$ triliun \\
\hline
\end{tabular}

Sumber: Gera, 2014

Salah satu faktor yang menyebabkan rendahnya capaian penerimaan pajak tersebut adalah adanya penghindaran dan penggelapan pajak oleh wajib pajak orang pribadi maupun badan (Maftuchan 2014). Penggelapan pajak di Indonesia merupakan persoalan nyata dengan modus yang semakin canggih, namun belum terantisipasi dengan efektif (Kompas.com 2013).

Penggelapan pajak (tax evasion) adalah usaha yang dilakukan oleh wajib pajak, apakah berhasil atau tidak, dengan mengatur suatu peristiwa sedemikian rupa untuk meminimalkan atau menghilangkan beban pajak, mengurangi atau sama sekali menghapus dengan memperhatikan ada atau tidaknya akibat-akibat pajak yang ditimbulkan berdasarkan ketentuan dan perundang-undangan perpajakan yang berlaku (Prasetyo 2010). Penggelapan pajak ini bisa dilakukan oleh wajib pajak dengan sengaja untuk mengurangi hutang pajak. Menurut Direktur Intelijen dan Penyelidikan Direktorat Jenderal Pajak, beberapa modus yang sering dipakai dalam penggelapan pajak adalah tidak melaporkan penjualan dalam SPT (Surat Pemberitahuan), menambahkan biaya-biaya fiktif, menggunakan faktur pajak palsu, tidak menyetorkan pajak yang dipotong atau dipungut dan rekayasa ekspor untuk mendapatkan restitusi Pajak Pertambahan Nilai (Hukumonline.com 2013). Menurut Rahman (2013), tindakan penggelapan pajak (tax evasion) tersebut dilakukan oleh wajib pajak karena dipengaruhi berbagai hal seperti pemahaman perpajakan yang minim, pelayanan aparat pajak yang tidak optimal dan sanksi yang tidak menimbulkan efek jera sehingga timbul peluang melakukan penggelapan pajak.

Latar belakang tindakan penggelapan pajak (tax evasion) biasanya disebabkan oleh persepsi bahwa pajak adalah suatu beban yang akan mengurangi kemampuan ekonomis seseorang (Reskino et al., 2013). Wajib pajak harus menyisihkan sebagian penghasilannya untuk membayar pajak. Padahal apabila tidak ada kewajiban pajak tersebut, uang yang dibayarkan untuk pajak bisa dipergunakan untuk menambah pemenuhan kebutuhan lainnya. Tidak hanya perusahaan (wajib pajak badan) saja yang melakukan penggelapan pajak (tax evasion), bahkan rata-rata tingkat penggelapan wajib pajak perorangan lebih tinggi dibandingkan dengan wajib pajak perusahaan (Ika, 2012)

Masih banyaknya kasus penggelapan pajak menyebabkan hilangnya potensi sumber penerimaan negara, sehingga perlu adanya langkah antisipatif dari berbagai pihak. Untuk mendasari langkah antisipatif tersebut perlu didasarkan pada studi terkait penggelapan pajak, secara khusus 
studi pada persepsi wajib pajak terhadap etika peggelapan pajak dan juga studi secara dini terhadap calon-calon wajib pajak. Penelitian ini akan meneliti tentang persepsi wajib pajak dan calon wajib pajak terhadap etika penggelapan pajak. Hasil penelitian ini diharapkan dapat mengevaluasi persepsi wajib pajak dan calon wajib pajak terhadap etika penggelapan pajak sehingga dapat menjadi bahan masukan untuk langkah antisipatif dalam menanggulangi penggelapan pajak. Calon wajib pajak merupakan salah satu kelompok masyarakat yang juga perlu diperhatikan. Surat Edaran Direktorat Jenderal Pajak No SE - 98/PJ/2011 tahun 2011 juga merepresentasikan perhatian fiskus kepada calon wajib pajak sebagai pembayar pajak di masa depan. Hal ini merupakan kepedulian pemerintah terhadap kesadaran calon wajib pajak, yang diwujudkan melalui penyuluhan dalam rangka membangun kesadaran (awareness) tentang perpajakan kepada para calon wajib pajak (DJP 2011).

Berbagai penelitian sebelumnya pernah dilakukan dalam rangka mengevaluasi persepsi mengenai etika penggelapan pajak. Prasetyo (2010) melakukan penelitian di wilayah Surakarta mengenai persepsi etis penggelapan pajak bagi wajib pajak. Hasil penelitian ini menunjukkan bahwa mayoritas dari pegawai swasta, wiraswasta dan juga pegawai negeri sipil tidak setuju dengan adanya berbagai bentuk praktik penggelapan pajak. Penelitian lain juga pernah dilakukan oleh Reskino et al. (2013) yang menemukan bahwa tidak terdapat perbedaan antara persepsi mahasiswa akuntansi program S1 dan mahasiswa akuntansi program S2 mengenai etika penggelapan pajak. Penelitian lain oleh Wicaksono (2014) menemukan adanya perbedaan persepsi yang signifikan antara mahasiswa ekonomi, hukum, dan psikologi mengenai etika penggelapan pajak. Mahasiswa ekonomi lebih menentang (tidak setuju) penggelapan pajak dibandingkan dengan dua kelompok lainnya, dan mahasiswa hukum paling tidak menentang penggelapan pajak diantara kelompok lainnya.

Penelitian kali ini akan mengembangkan penelitian Prasetyo (2010), dengan meneliti persepsi etika penggelapan wajib pajak dan calon wajib pajak. Wajib pajak yang akan diteliti adalah wajib pajak orang pribadi di Salatiga. Adapun calon wajib pajak yang diteliti adalah mahasiswa, khususnya mahasiswa program akuntansi dan manajemen. Pengembangan dari penelitian Prasetyo (2010) adalah adanya penambahan kelompok calon wajib pajak (khususnya mahasiswa program akuntansi dan manajemen) sebagai objek penelitian. Prasetyo (2010) hanya meneliti persepsi etika penggelapan pajak pada wajib pajak orang pribadi. Namun studi secara dini pada calon wajib pajak juga dirasa perlu sebagai bahan masukan atas upaya antisipatif yang dapat dilakukan sejak dini untuk menekan penggelapan pajak, yang juga sesuai dengan semangat pemerintah untuk membina calon wajib pajak seperti tertuang dalam Surat Edaran Direktorat Jenderal Pajak No.SE - 98/PJ/2011 tahun 2011. Calon wajib pajak yang diteliti adalah mahasiswa program akuntansi dan manajemen. Salah satu nilai yang dipromosikan oleh ilmu akuntansi adalah akuntabilitas, yaitu suatu kewajiban pemegang amanah (agent) untuk memberikan pertanggungjawaban, menyajikan, melaporkan, dan mengungkapkan segala aktivitas dan kegiatan yang menjadi tanggungjawabnya kepada pihak pemberi amanah (principal) yang memiliki hak dan kewenangan untuk meminta pertanggungjawaban tersebut (Mardiasmo 2004). Dalam pemenuhan kewajiban pajak, akuntabilitas 
dapat dipahami sebagai kewajiban seorang wajib pajak untuk mempertanggungjawabkan kewajibannya dalam hal ini menyajikan dan melaporkan pajak terutang kepada fiskus atau aparat pajak sesuai dengan keadaan sebenarnya. Sementara penambahan mahasiswa program studi manajemen sebagai objek penelitian didasari dengan pemikiran bahwa mahasiswa manajemen di kemudian hari akan menjadi pelaku usaha atau manajemen dalam suatu perusahan yang memegang peranan penting termasuk peran dalam pengambilan keputusan terkait pajak. Berdasarkan pemaparan di atas, maka penelitian ini bertujuan untuk mengetahui persepsi calon wajib pajak (mahasiswa) dan wajib pajak terhadap etika penggelapan pajak.

Hasil penelitian ini diharapkan dapat bermanfaat bagi beberapa pihak untuk menambah wawasan bagi para akademisi maupun masyarakat luas, menjadi bahan referensi untuk penelitian selanjutnya, dan menjadi bahan masukan untuk sosialisasi/edukasi anti penggelapan pajak.

\section{Tinjauan Pustaka}

\subsection{Teori- Teori yang Digunakan}

\subsubsection{Theory of Reasoned Action}

Ajzen dan Fishbein (1980) dalam Azwar (2002) merumuskan theory of reasoned action yang menjelaskan bahwa perilaku manusia pada dasarnya dilakukan atas kemauan sendiri. Teori ini didasarkan pada asumsi bahwa manusia umumnya melakukan sesuatu dengan cara-cara yang masuk akal, mempertimbangkan semua informasi yang ada, dan memperhitungkan implikasi tindakan mereka. Teori ini mempertimbangkan aspek sikap, norma subjektif, niat dan perilaku manusia. Teori ini mengungkapkan bahwa niat merupakan fungsi dari dua faktor dasar, yaitu sikap individu terhadap perilaku dan adalah persepsi individu terhadap tekanan sosial untuk melakukan atau untuk tidak melakukan perilaku yang bersangkutan (norma subjektif). Secara sederhana teori ini menjelaskan bahwa apabila seseorang memandang suatu perbuatan itu sebagai hal yang positif (sikap) dan bila ia percaya bahwa orang lain ingin agar ia melakukannya (norma subjektif) maka akantimbul niat dari dirinya untuk melakukan suatu perbuatan, sehingga akhirnya dapat terjadi keputusan berperilaku tertentu.Terkait dengan perilaku penggelapan pajak, dapat dijelaskan dengan teori ini bahwa jika wajib pajak menilai bahwa penggelapan pajak adalah hal yang tidak baik (sikap negatif) dan orang-orang sekitar yang dianggap penting atau dijadikan panutan menganggap bahwa perilaku penggelapanpajak sudah seharusnya tidak dilakukan, maka akan timbul niat berperilaku tidak menggelapkan pajak dan selanjutnya dapat menjadi perilaku.

Konsep sikap terhadap perilaku menjadi elemen penting dalam penelitian ini. Menurut Thurstone et al. dalam Azwar (2002), sikap adalah suatu bentuk evaluasi atau reaksi perasaan. Sikap itu sendiri timbul karena adanya kesiapan untuk bereaksi terhadap suatu objek dengan cara-cara tertentu (Chave et al. dalam Azwar 2002). Terbentuknya sikap menurut Katz et al. dalam Azwar (2002), merupakan respon kognitif yaitu respon dari persepsi dan pernyataan manusia mengenai apa yang 
diyakini. Terkait dengan sikap atas penggelapan pajak, keyakinan bahwa penggelapan pajak adalah hal yang tidak etis (persepsi etika) dapat direspon menjadi sikap bahwa penggelapan pajak adalah perilaku yang negatif.

\subsubsection{Penggelapan Pajak}

Secara umum pajak dapat diartikan sebagai pungutan yang dibebankan oleh pemerintah atas pendapatan, kekayaan dan keuntungan modal orang pribadi dan perusahaan, serta hak milik yang tidak bergerak. Mardiasmo (2009) mendefinisikan penggelapan pajak (tax evasion) sebagai usaha yang dilakukan oleh wajib pajak untuk meringankan beban pajak dengan cara melanggar undangundang. Penggelapan pajak ini dilakukan dengan menggunakan cara yang tidak legal. Para wajib pajak mengabaikan ketentuan formal perpajakan yang menjadi kewajibannya, memalsukan dokumen atau mengisi data dengan tidak lengkap dan tidak benar.

Pembangunan dapat terhambat oleh penggelapan pajak karena dana dari pembayaran pajak tidak masuk keuangan negara. Pemahaman ini juga kemudian dikuatkan oleh Rahayu (2010) yang mendefinisikan penggelapan pajak (tax evasion) sebagai usaha untuk membayar pajak terhutang dengan sekecil mungkin dan cenderung melakukan penyelundupan pajak, yang tentunya melanggar peraturan perundang undangan perpajakan. Kondisi ini merupakan tindakan minimalisasi pajak atau tindakan ilegal yang dilakukan oleh wajib pajak.

Menurut Murni et al. (2013) dalam Rachmadi (2014) kecenderungan wajib pajak melakukan kecurangan dikarenakan beberapa hal antara lain: pertama, tingginya pajak yang harus dibayar. Semakin tinggi jumlah pajak yang harus dibayar oleh wajib pajak, semakin tinggi kemungkinan wajib pajak berperilaku curang. Kedua, makin tinggi uang suap yang harus dikeluarkan oleh wajib pajak, maka makin kecil kemungkinan wajib pajak melakukan kecurangan. Ketiga, makin tinggi kemungkinan terungkap apabila melakukan kecurangan, maka makin rendah kecenderungan wajib pajak berlaku curang. Keempat, makin besar ancaman hukuman dan sanksi yang diterapkan kepada pelaku kecurangan, maka semakin kecil kecenderungan wajib pajak melakukan kecurangan.

Dengan demikian penggelapan pajak dapat didefinisikan sebagai suatu upaya atau tindakan yang merupakan pelanggaran terhadap ketentuan peraturan perundang-undangan perpajakan seperti berikut menurut Brotoharjo (2007) dalam Prasetyo (2010): (1)Tidak dapat memenuhi pengisian Surat Pemberitahuan tepat waktu; (2) Tidak dapat memenuhi pembayaran pajak tepat waktu; (3) Tidak dapat memenuhi pelaporan dan pengurangannya secara lengkap dan benar; (4) Tidak dapat memenuhi kewajiban memelihara pembukuan; (5) Tidak dapat memenuhi kewajiban menyetorkan pajak penghasilan para karyawan yang dipotong dan pajak-pajak lainnya yang telah dipungut; (6) Tidak dapat memenuhi kewajiban membayar taksiran pajak terutang; (7) Tidak dapat memenuhi permintaan fiskus akan informasi pihak ketiga; (8) Pembayaran dengan cek kosong bagi negara yang dapat melakukan pembayaran pajaknya dengan cek; (9) Melakukan penyuapan terhadap aparat perpajakan dan atau tindakan intimidasi lainnya. 


\subsubsection{Etika}

Etika berasal dari kata ethos sebuah kata dari Yunani, yang diartikan identik dengan moral atau moralitas dan dijadikan sebagai pedoman atau ukuran bagi tindakan manusia dengan penilaian baik atau buruk dan benar atau salah (Untung 2012). Dalam pengertian ini etika berkaitan dengan kebiasaan hidup yang baik, baik pada diri sendiri maupun pada suatu masyarakat atau kelompok masyarakat. Istilah etika sangat berhubungan dengan tata krama, sopan santun, pedoman moral, norma susila, dan lain-lain yang mana hal-hal ini berhubungan juga dengan norma-norma yang ada di dalam masyarakat. Keraf (1998) dalam Prasetyo (2010), menyatakan bahwa etika berkaitan dengan nilai-nilai, tata cara hidup yang baik, aturan hidup yang baik, dan segala kebiasaan yang dianut dan diwariskan satu orang ke orang yang lain atau dari satu generasi ke generasi yang lain.

Etika merupakan pernyataan benar atau salah yang menetukan perilaku seseorang tergolong bermoral atau tidak bermoral, baik atau buruk. Pernyataan etika ini kemudian dituangkan dalam bentuk prinsip-prinsip etika yang secara normatif dipergunakan untuk membimbing tindakan seseorang menjadi perilaku yang bermoral (Sigit, 2012).

\subsubsection{Persepsi}

Dalam psikologi, persepsi dapat diartikan sebagai proses perolehan, penafsiran, pemilihan dan pencarian informasi untuk dipahami dengan menggunakan pengindraan (penglihatan, pendengaran, peraba dan sebagainya) (Surwono 1999). Menurut Prasetyo (2010), persepsi adalah pengalaman tentang objek, peristiwa, atau hubungan-hubungan yang diperoleh dengan menyimpulkan informasi dan menafsirkan pesan. Presepsi adalah suatu proses petunjuk petunjuk inderawi (sensory) dan pengalaman masa lampau yang relevan diorganisasikan untuk memberikan kepada kita gambaran yang terstruktur dan bermakna pada suatu situasi tertentu.

\subsubsection{Etika Penggelapan Pajak dalam Pespektif Sistem Pajak}

Menurut Rahman (2013), sistem perpajakan Indonesia memberikan kebebasan yang bertanggungjawab kepada wajib pajak dalam memenuhi kewajiban membayar pajak. Disisi lain, aparat perpajakan juga berperan aktif dalam melaksanakan pengendalian administrasi pemungutan pajak yang meliputi tugas-tugas pembinaan, pelayanan, pengawasan dan penerapan sanksi perpajakan. Pembinaan terhadap masyarakat yang merupakan bagian dari wajib pajak dilakukan melalui berbagai upaya, antara lain memberikan penyuluhan pengetahuan perpajakan, baik melalui media masa maupun pembinaan secara langsung kepada masyarakat (Siahaan, 2010). Sistem perpajakan yang baik menurut Suminarsasi (2012) adalah pengelolaan uang pajak yang dapat dipertanggungjawabkan, petugas pajak yang kompeten dan tidak korup serta prosedur perpajakan yang tidak berbelit-belit. Semakin baik suatu sistem perpajakan, maka perilaku penggelapan pajak dianggap sebagai perilaku yang tidak etis. Akan tetapi apabila sistem perpajakan berjalan dengan tidak baik, maka perilaku penggelapan pajak dianggap sebagai perilaku yang 
cenderung etis. Dalam sebuah situasi dimana dana pajak dikelola dengan prosedur yang tidak transparan dan dikelola dengan moralitas yang buruk maka wajib pajak akan menjadi enggan untuk berperilaku patuh sebab mereka ragu apakah dana pajak dapat dipergunakan sebagaimana mestinya atau tidak. Kondisi tersebut juga dapat membuat para wajib pajak menganggap bahwa tindakan tidak patuh pajak (menggelapkan pajak) menjadi wajar.

\subsubsection{Etika Penggelapan Pajak dalam Perspektif Keadilan}

Aspek keadilan pajak menurut Musgrave dalam Waluyo (2013) dibagi dua yaitu: pertama, benefit principle dimana setiap wajib pajak harus membayar pajak sejalan dengan manfaat yang dinikmatinya dari pemerintah. Kedua adalah ability principle yang berarti setiap wajib pajak membayar kewajiban pajaknya sesuai dengan dasar kemampuan membayar. Waluyo (2013) juga menambahkan bahwa aspek keadilan dalam pemungutan pajak, dibedakan menjadi dua bagian: pertama, keadilan horizontal yaitu beban pajak dikenakan dengan besaran sama atas semua wajib pajak yang memperoleh penghasilan yang sama dengan jumlah tanggungan yang sama, tanpa membedakan jenis penghasilan atau sumber penghasilan. Kedua adalah keadilan vertikal, dimana keadilan dapat dirumuskan bahwa pemungutan pajak dikatakan adil jikalau orang dalam kondisi ekonomis yang sama dikenakan pajak yang sama, demikian juga sebaliknya. Aspek adil juga terkait dengan penegakan aturan main dalam pelaksanaan hak dan kewajiban pajak.

Menurut Suminarsasi (2012) setiap masyarakat mempunyai kewajiban kepada negaranya untuk membayar pajak, dan negara mempunyai tanggungjawab mensejahterakan rakyatnya secara adil. Kondisi pelaksanaan perpajakan yang dinilai tidak adil antara lain tampak dari tidak ditegakkannya aturan hukum pajak secara baik, wajib pajak tidak mampu secara ekonomi dan dana pajak digunakan untuk hal yang tidak adil (misalnya perang). Dalam situasi keadilan yang dijunjung tersebut, wajib pajak dapat menjadi enggan untuk memenuhi kewajiban pajaknya. Wajib pajak akan menganggap perilaku tidak patuh pajak sebagai hal yang wajar. Hal ini berarti para wajib pajak menganggap bahwa semakin tinggi keadilan perpajakannya maka perilaku penggelapan pajak dianggap sebagai perilaku yang tidak etis namun apabila keadilan perpajakannya semakin rendah, maka perilaku penggelapan pajak dianggap sebagai perilaku yang etis (Suminarsasi 2012).

\subsubsection{Etika Penggelapan Pajak Terkait Diskriminasi}

Menurut Danandjaja (2003), diskriminasi adalah perlakuan yang tidak seimbang terhadap perorangan, atau kelompok, berdasarkan sesuatu, biasanya bersifat kategorikal, atau atributatribut khas, seperti berdasarkan ras, kesukubangsaan, agama, atau keanggotaan kelas-kelas sosial. Diskriminasi dalam bidang perpajakan menunjuk pada kondisi dimana pemerintah memberikan pelayanan perpajakan dengan tidak seimbang terhadap masyarakat maupun wajib pajak. Semakin kecil diskriminasi maka perilaku penggelapan pajak dianggap sebagai perilaku yang tidak etis, namun jika diskriminasi semakin besar maka perilaku penggelapan pajak dapat dianggap sebagai perilaku yang etis. 


\subsection{Penelitian Terdahulu}

Penelitian terdahulu pernah dibuat untuk mengetahui faktor-faktor yang memengaruhi penggelapan pajak, yang antara lain menemukan bahwa keadilan, sistem perpajakan berpengaruh positif terhadap persepsi wajib pajak mengenai penggelapan pajak, namun kualitas pelayanan, sanksi perpajakan dan kemungkinan terdeteksinya kecurangan tidak terbukti berpengaruh terhadap persepsi wajib pajak mengenai penggelapan pajak (Yetmi dan Yulistia 2014). Adapun Rahman (2013) yang juga melakukan penelitian serupa namun menemukan hasil yang sedikit berbeda, dimana dibuktikan keadilan dan adanya diskriminasi berpengaruh positif terhadap penggelapan pajak. Adapun sistem perpajakan dan kemungkinan terdeteksi kecurangan berpengaruh negatif terhadap penggelapan pajak.

Prasetyo (2010) meneliti mengenai persepsi etis penggelapan pajak bagi wajib pajak di wilayah Surakarta, dilatar belakangi karena ada permasalahan baru bagi pemerintah Indonesia yaitu kasus penggelapan pajak. Penelitian ini bertujuan untuk mengetahui persepsi etis penggelapan pajak bagi wajib pajak, dengan menggunakan metode survey. Penelitian ini menemukan mayoritas pegawai swasta, wiraswasta dan juga pegawai negeri sipil tidak setuju dengan adanya berbagai bentuk praktik penggelapan pajak.

Penelitian sebelumnya mengenai persepsi mahasiswa terhadap etika penggelapan pajak pernah dilakukan oleh Wicaksono (2014) dan Reskino et al. (2013). Penelitian Wicaksono (2014) dilatar belakangi dengan adanya perbedaan persepsi antar kelompok menurut disiplin ilmu, karena penggelapan pajak dapat dikatakan etis jika dikaitkan dalam kodisi tertentu. Penelitian Wicaksono (2014) bertujuan untuk menganilisis apakah ada perbedaan persepsi yang signifikan antara mahasiswa ekonomi, hukum, dan psikologi mengenai etika penggelapan pajak, serta mengidentifikasi kelompok mana yang lebih menentang dan tidak menentang penggelapan pajak. Penelitian ini menemukan bahwa terdapat perbedaan persepsi yang signifikan antara mahasiswa ekonomi, hukum, dan psikologi mengenai etika penggelapan pajak. Mahasiswa ekonomi lebih menentang (tidak setuju) penggelapan pajak dibandingkan dengan dua kelompok lainnya dan mahasiswa hukum paling tidak menentang penggelapan pajak diantara kelompok lainnya. Penelitian lain oleh Reskino et al. (2013) dilatar belakangi oleh adanya perbedaan perspektif mengenai penggelapan pajak (tax evasion). Penelitian yang bersifat kualitatif ini memiliki tujuan untuk mengetahui apakah terdapat perbedaan persepsi antara mahasiswa akuntansi Program S1 dan mahasiswa akuntansi Program S2 mengenai penggelapan pajak (tax evasion). Sampel penelitian ini diperoleh dengan menggunakan metode judgement sampling. Hasil penelitian menunjukkan bahwa tidak terdapat perbedaan antara persepsi mahasiswa akuntansi program $\mathrm{S} 1$ dan mahasiswa akuntansi program S2 mengenai penggelapan pajak. Namun mahasiswa akuntansi program S1 lebih menganggap penggelapan pajak adalah tidak etis dibandingkan dengan mahasiswa akuntansi Program S2, walaupun perbedaan tersebut tidak signifikan. 


\subsection{Kerangka Pemikiran}

Penelitian ini menginvestigasi persepsi calon wajib pajak (mahasiswa $\mathrm{S} 1$ \& S2 program akuntansi dan manajemen) dan wajib pajak orang pribadi mengenai etika penggelapan pajak (tax evasion). Kerangka pemikiran dapat dilihat pada gambar 1.

Gambar 1

Kerangka Pemikiran

\begin{tabular}{|c|c|c|}
\hline \multirow[b]{2}{*}{$\begin{array}{c}\text { Penerimaan pajak } \\
\text { tidak mencapai target } \\
\text { (Gera, 2014) }\end{array}$} & & \\
\hline & $\begin{array}{c}\text { Perlu adanya } \\
\text { langkah antisipatif }\end{array}$ & \multirow{2}{*}{$\begin{array}{l}\text { Dirumuskan dengan berdasarkan } \\
\text { studi terkait penggelapan pajak pada } \\
\text { wajib pajak dan calon wajib pajak. } \\
\text { Tujuan penelitian } \\
\text { mengetahuipersepsi calon wajib } \\
\text { pajak dan wajib pajak terhadap etika } \\
\text { penggelapan pajak. }\end{array}$} \\
\hline (Uela, CU14) & & \\
\hline
\end{tabular}

Disebabkan oleh

penghidaran dan

penggelapan pajak

(Maftuchan, 2014)

\section{MetodePenelitian}

\subsection{Jenis Penelitian}

Jenis penelitian ini adalah penelitian survei, yaitu penelitian kuantitatif dengan menggunakan pertanyaan terstruktur yang sama pada setiap orang, kemudian semua jawaban yang diperoleh peneliti dicatat, diolah, dan dianalisis (Sugiyono 2014). Penelitian ini termasuk dalam penelitian deskriptif tidak membuat perbandingan atau hubungan antar variabel, namun hanya ingin mengetahui nilai variabel mandiri.

\subsection{Populasi dan Sampel}

Populasi yang digunakan dalam penelitian ini adalah seluruh wajib pajak orang pribadi di Salatiga dan mahasiswa (akuntansi dan manajemen) yang berada di Universitas Kristen Satya Wacana. Penentuan jumlah sampel penelitian ini mengacu pada Roscoe (1975) dalam Sekaran (2006), yang menyatakan ukuran sampel lebih dari 30 dan kurang dari 500 adalah tepat untuk kebanyakan penelitian dan jika sampel dipecah ke dalam subsampel, ukuran sampel minimum disarankan sebesar 30 untuk tiap kategori. Adapun teknik pengambilan sampel penelitian ini dilakukan dengan metode quota sampling, yaitu teknik menentukan sampel dari populasi yang mempunyai ciiri-ciri tertentu sampai jumlah (kuota) yang diinginkan (Sugiyono 2013). Dengan menetapkan jumlah responden sebanyak 30 orang untuk tiap-tiap kategori, yaitu wajib pajak orang pribadi dengan penghasilan besumber pekerjaan dan usaha, serta calon wajib pajak dari mahasiswa program studi akuntansi dan manajemen. 
Responden wajib pajak dibagi dari kelompok mereka yang berpenghasilan dari pekerjaan dan usaha kerena kedua kategori ini memiliki karakteristik kewajiban pajak yang berbeda. Adapun untuk sampel mahasiswa, dipilih mahasiswa yang sudah mengambil mata kuliah Hukum Pajak, karena peneliti berasumsi bahwa mereka memiliki pengetahuan dasar tentang pajak. Pengetahuan dasar tentang pajak diperlukan bagi responden dalam penelitian ini, supaya responden calon wajib pajak dapat menjawab pertanyaan dengan logis dan sadar, karena sudah mengetahui tentang sistem perpajakan di Indonesia.

Pelaksanaan penelitian dan pengambilan data dilakukan pada bulan April sampai dengan Mei 2015. Teknik pengumpulan data dalam penelitian ini menggunakan wawancara semi terstruktur dengan para informan kunci yang menghasilkan data primer. Selain itu, dokumentasi juga digunakan dalam penelitian ini dengan sifat dokumen resmi internal. Moleong (2014) mengatakan dokumen internal berupa memo, pengumuman, instruksi, aturan suatu lembaga yang digunakan dalam kalangan sendiri. Dokumentasi dilakukan terhadap data-data dari Kantor Pelayanan Pajak (KPP) Pratama Gubeng Surabaya yang berupa laporan target dan realisasi bidang pendapatan dari pajak UMKM, dokumentasi sosialisasi Peraturan Pemerintan Nomor 46 Tahun 2013, serta data-data lainnya yang berkenaan dengan pajak UMKM.

\subsection{Sumber dan Teknik Pengumpulan Data}

Penelitian ini menggunakan sumber data primer, berupa persepsi calon wajib pajak (mahasiswa FEB UKSW) dan wajib pajak mengenai etika penggelapan pajak, yang dikumpulkan menggunakan kuesioner. Kuesioner yang digunakan dalam penelitian ini mengadopsi dari penelitian Reskino et al. (2013). Kuesioner yang berisikan pertanyaan-pertanyaan akan diberikan secara langsung dan akan diisi responden secara langsung dengan mengisi alternatif jawaban yang sudah tersedia. Data yang terkumpul selanjutnya akan dianalisis dengan metode deskriptif kuantitatif.

Adapun seluruh variabel penelitian akan diukur dengan menggunakan skala likert diberi skor satu menandakan pendapat sangat tidak setuju, sampai skor lima yang menandakan pendapat sangat setuju. Skala likert dikatakan interval karena pernyataan sangat setuju mempunyai tingkat atau prefensi yang "lebih tinggi" dari setuju dan setuju "lebih tinggi" dari ragu-ragu. Pemberian skor ini mengikuti penelitian-penelitian sebelumnya yaitu penelitian Prasetyo (2010) dan Rachmadi (2014). Tabel 2 berikut ini merupakan indikator dari variabel-variabel penelitian yang didasarkan dari penelitian Reskino et al. (2013). 
Tabel 2

Operasionalisasi Variabel

\begin{tabular}{|c|c|}
\hline Variabel & Indikator \\
\hline $\begin{array}{l}\text { Persepsi calon wajib pajak dan wajib } \\
\text { pajak mengenai penggelapan pajak (tax } \\
\text { evasion) dari sudut pandang sistem } \\
\text { pajak. }\end{array}$ & $\begin{array}{l}\text { 1. Penggelapan pajak adalah etis, jika tarif pajak yang } \\
\text { dikenakan terlalu tinggi. } \\
\text { 2. Penggelapan pajak adalah etis, jika pemerintah tidak } \\
\text { memberitahukan jenis dari pajak yang dikenakan (pajak atas } \\
\text { apa). } \\
\text { 3. Penggelapan pajak adalah etis, jika sistem pajak berjalan } \\
\text { dengan tidak adil. } \\
\text { 4. Penggelapan pajak adalah etis, jika sistem pajak berjalan } \\
\text { dengan tidak efesien. } \\
\text { 5. Penggelapan pajak adalah etis, jika sebagian besar porsi } \\
\text { dari pajak yang dikumpulkan dipergunakan secara tidak } \\
\text { merata, misalnya masih banyak daerah-daerah yang tidak } \\
\text { merasakan dampak pembangunan akan adanya pajak. } \\
\text { 6. Penggelapan pajak adalah etis, jika petugas pajak tidak } \\
\text { memiliki moralitas pajak yang baik. } \\
\text { 7. Penggelapan pajak adalah etis, jika saya tidak memiliki } \\
\text { kemampuan untuk menghitung jumlah pajak yang } \\
\text { disetorkan. }\end{array}$ \\
\hline $\begin{array}{l}\text { Persepsicalon wajib pajak dan wajib } \\
\text { pajak mengenai penggelapan pajak } \\
\text { (tax evasion) dari sudut pandang } \\
\text { keadilan pajak. }\end{array}$ & $\begin{array}{l}\text { 8. Penggelapan pajak adalah etis, jika sebagian besar pajak } \\
\text { digunakan untuk proyek yang tidak memberikan keuntungan } \\
\text { bagi saya. } \\
\text { 9. Penggelapan pajak adalah etis, jika penegak hukum yang } \\
\text { ada belum memadai dalam menangani kasus pajak yang } \\
\text { terjadi. } \\
\text { 10. Penggelapan pajak adalah etis, jika orang lain juga } \\
\text { melakukannya. } \\
\text { 11. Penggelapan pajak adalah etis, jika secara signifikan } \\
\text { sebagian besar pajak yang disetorkan dikorupsi oleh pihak- } \\
\text { pihak yang tidak bertanggung jawab. } \\
\text { 12. Penggelapan pajak adalah etis, jika kemungkinan resiko } \\
\text { untuk ditangkap/dipenjarakan atas tindakan penggelapan } \\
\text { tersebut kecil. } \\
\text { 13. Penggelapan pajak adalah etis, jika pajak digunakan untuk } \\
\text { mendukung sebuah perang yang pada akhirnya menimbulkan } \\
\text { ketidakadilan. } \\
\text { 14. Penggelapan pajak adalah etis, jika saya tidak mampu untuk } \\
\text { membayar pajak. } \\
\text { 15. Penggelapan pajak adalah etis, jika otoritas pajak yang ada } \\
\text { kurang memadai. }\end{array}$ \\
\hline $\begin{array}{l}\text { Persepsicalon wajib pajak dan } \\
\text { wajib pajak r mengenai } \\
\text { penggelapan pajak (tax evasion) } \\
\text { dari sudut pandang diskriminasi }\end{array}$ & $\begin{array}{l}\text { 16. Penggelapan pajak adalah etis, jika pemerintah } \\
\text { mendiskriminasi saya karena agama, ras, dan latar } \\
\text { belakang etnis/budaya. }\end{array}$ \\
\hline
\end{tabular}

Sumber: Reskino et al. (2013)

Adapun langkah-langkah analisis adalah sebagai berikut.

1. Melakukan pengujian validitas dan reabilitas

2. Perhitungan skor persepsi masing-masing kelompok responden

3. Mengklasifikasi skor persepsi dalam kategori jawaban dengan metode interval.

$$
I=\frac{\operatorname{Max}-\operatorname{Min}}{K}
$$

Keterangan:

I : Interval

Max : Nilai jawaban tertinggi, yaitu 5 
Min : Nilai jawaban terendah, yaitu 1

K: Klasifikasi yang hendak dibuat atau ditetapkan sebanyak 5klasifikasi

Dimana:

$$
\begin{array}{ll}
1,0-1,80 & \text { : Sangat Tidak Setuju } \\
1,81-2,60 & \text { : Tidak Setuju } \\
2,61-3,40 & : \text { Ragu-ragu } \\
3,41-4,20 & \text { : Setuju } \\
4,21-5,00 & \text { : Sangat Setuju }
\end{array}
$$

4. Melakukan analisis deskriptif pada masing-masing variabel.

\subsection{Gambaran Umum Responden}

Penelitian ini dilakukan terhadap calon wajib pajak dan wajib pajak di wilayah Salatiga. Data primer diperoleh dengan menggunakan kuesioner yang diberikan kepada responden. Peneliti mengambil sampel sebanyak 60 calon wajib pajak dan 60 wajib pajak di wilayah Salatiga. Adapun penyebaran kuesioner yang disebar sebanyak 120 dan yang kembali pun demikian yaitu 120 kuesioner. Peneliti mengolah data kuesioner secara penuh 100\% atau 120 eksemplar kuesioner.

Statistik deskriptif karakteristik responden dalam penelitian ini dapat dilihat pada tabel berikut.

Tabel 3

Statistik Dekriptif Gambaran Responden

\begin{tabular}{|l|l|l|}
\hline Jenis Kelamin & Jumlah & Presentase \\
\hline Laki-laki & 72 & $60 \%$ \\
\hline Perempuan & 48 & $40 \%$ \\
\hline Jumlah & 120 & $100 \%$ \\
\hline Pekerjaan & & \\
\hline Pegawai & 30 & $25 \%$ \\
\hline Wirausaha & 30 & $25 \%$ \\
\hline Mahasiswa Akuntansi & 30 & $25 \%$ \\
\hline Mahasiswa Manajemen & 30 & $25 \%$ \\
\hline Jumlah & 120 & $100 \%$ \\
\hline
\end{tabular}

Sumber: Data primer diolah, 2015

Dari 120 responden penelitian ini, 72 orang di antaranya adalah laki-laki dan 48 di antaranya adalah perempuan. Apabila dilihat dari latar belakang pekerjaannya, maka diketahui bahwa responden memiliki ragam bidang pekerjaan yang dibagi dalam tiga kelompok besar antara lain pegawai, wirausaha dan mahasiswa. Kelompok pegawai dan wirausaha mewakili responden kategori wajib pajak. Adapun kelompok mahasiswa mewakili responden kategori calon wajib pajak. Responden yang memiliki pekerjaan sebagai pegawai berjumlah 30 orang atau $25 \%$, yang terdiri dari PNS, Karyawan BUMN, guru dan karyawan swasta. Selanjutnya responden berlatar belakang pekerjaan wirausaha sebanyak 30 orang atau $25 \%$, yang terdiri dari pedagang, pemilik persewaan mobil dan motor, pemilik rumah kos dan pemilik restoran. Kategori terakhir merupakan mahasiswa yang terdiri dari mahasiswa/i program studi S1 Akuntansi, S1 Manajemen, S2 Akuntansi dan S2 
Manajemen. Mahasiswa program Akuntansi serta Manajemen (baik S1 maupun S2), masing-masing berjumlah 30 orang atau $25 \%$.

\section{Hasil dan Pembahasan}

Berikut ini adalah ringkasan hasil pengujian validitas dan reliabilitas:

Tabel 4

Hasil Uji Validitas dan Reliabilitas

\begin{tabular}{|c|c|c|}
\hline Pertanyaan & Sig. & Keterangan \\
\hline Pertanyaan 1 & 0.000 & Valid \\
\hline Pertanyaan 2 & 0.000 & Valid \\
\hline Pertanyaan 3 & 0.000 & Valid \\
\hline Pertanyaan 4 & 0.000 & Valid \\
\hline Pertanyaan 5 & 0.000 & Valid \\
\hline Pertanyaan 6 & 0.000 & Valid \\
\hline Pertanyaan 7 & 0.000 & Valid \\
\hline Pertanyaan 8 & 0.000 & Valid \\
\hline Pertanyaan 9 & 0.000 & Valid \\
\hline Pertanyaan 10 & 0.000 & Valid \\
\hline Pertanyaan 11 & 0.000 & Valid \\
\hline Pertanyaan 12 & 0.000 & Valid \\
\hline Pertanyaan 13 & 0.000 & Valid \\
\hline Pertanyaan 14 & 0.000 & Valid \\
\hline Pertanyaan 15 & 0.000 & Valid \\
\hline Pertanyaan 16 & 0.000 & Valid \\
\hline Variabel & Cronbach Alpha & Keterangan \\
\hline Sistem Pajak & 0,889 & Reliable \\
\hline Keadilan Pajak & 0,871 & Reliable \\
\hline
\end{tabular}

Sumber: Data primer diolah, 2015

Berdasarkan pengujian validitas dan reliabilitas terhadap instrumen survei, maka dapat disimpulkan bahwa instrumen yang dipakai valid dan reliable, sehingga seluruh data dapat dipakai dalam analisis hasil penelitian. Seluruh pengukuran uji validitas menunjukan tingkat sig. 000, yang berarti data tersebut valid. Sementara data dikatakan reliable karena nilai Cronbach Alpha > 0,6 (Gozhali 2005). Hasil olahan data, menemukan bawha nilai Cronbach Alpha dari variabel sistem pajak adalah 0,889 dan variabel keadilan pajak 0,871 > dari 0,6 maka dapat disimpulkan data tersebut reliable. 
Tabel 5

Tabel Rata-Rata Skor Jawaban Responden

\begin{tabular}{|c|c|c|c|c|c|c|c|}
\hline \multirow{2}{*}{ No } & \multicolumn{3}{|c|}{ Rata-Rata Wajib Pajak } & \multicolumn{2}{c|}{ Rata-Rata Calon Wajib Pajak } & \multirow{2}{*}{ Total } \\
\cline { 2 - 7 } & Pegawai & Wirausaha & $\begin{array}{c}\text { Wajib } \\
\text { Pajak }\end{array}$ & $\begin{array}{c}\text { Mhs } \\
\text { Akuntansi }\end{array}$ & $\begin{array}{c}\text { Mhs } \\
\text { Manaj. }\end{array}$ & $\begin{array}{c}\text { Calon Wajib } \\
\text { Pajak }\end{array}$ & \\
\hline 1. & 2,33 & 2,23 & 2,28 & 2,03 & 2,13 & 2,08 & 2,18 \\
\hline 2. & 2,80 & 2,77 & 2,78 & 2,50 & 2,73 & 2,63 & 2,70 \\
\hline 3. & 2,67 & 2,77 & 2,72 & 2,53 & 2,80 & 2,67 & 2,69 \\
\hline 4. & 2,63 & 2,77 & 2,70 & 2,40 & 2,90 & 2,65 & 2,68 \\
\hline 5. & 2,57 & 2,67 & 2,62 & 2,13 & 3,13 & 2,63 & 2,63 \\
\hline 6. & 2,87 & 2,90 & 2,88 & 2,60 & 3,37 & 2,98 & 2,93 \\
\hline 7. & 2,10 & 2,33 & 2,22 & 2,00 & 2,43 & 2,22 & 2,22 \\
\hline 8. & 2,20 & 2,43 & 2,32 & 1,87 & 2,17 & 2,02 & 2,17 \\
\hline 9. & 2,77 & 2,67 & 2,27 & 2,27 & 2,80 & 2,53 & 2,63 \\
\hline 10. & 1,90 & 2,00 & 1,95 & 1,80 & 1,83 & 1,82 & 1,88 \\
\hline 11. & 2,73 & 2,73 & 2,73 & 2,50 & 3,33 & 2,92 & 2,83 \\
\hline 12. & 2,47 & 2,43 & 2,45 & 1,90 & 2,23 & 2,07 & 2,26 \\
\hline 13. & 2,93 & 2,77 & 2,85 & 2,37 & 2,67 & 2,52 & 2,68 \\
\hline 14 & 2,63 & 2,80 & 2,72 & 2,27 & 2,53 & 2,40 & 2,56 \\
\hline 15 & 2,47 & 2,60 & 2,53 & 2,00 & 2,50 & 2,25 & 2,39 \\
\hline 16. & 2,47 & 2,40 & 2,43 & 2,27 & 2,33 & 2,30 & 2,37 \\
\hline Rata-rata & 2,53 & 2,58 & 2,42 & 2,21 & 2,62 & 2,56 & 2,49 \\
\hline Sistem Pajak & 2,57 & 2,63 & 2,60 & 2,31 & 2,79 & 2,55 & 2,58 \\
\hline Keadilan & 2,51 & 2,55 & 2,53 & 2,12 & 2,51 & 2,31 & 2,42 \\
\hline Pajak & 2,47 & 2.40 & 2,43 & 2,27 & 2,33 & 2,30 & 2,37 \\
\hline Diskriminasi & 2,47 & & & &
\end{tabular}

Sumber: Data primer diolah, 2015

Berdasarkan tabel 5 diatas, diperoleh informasi bahwa kelompok responden wajib pajak memiliki nilai skor rata-rata 2,42, yang berarti kelompok responden wajib pajak tidak setuju bahwa penggelapan pajak adalah hal yang etis dengan berbagai alasan. Skor terendah adalah 1,95 pada pertanyaan nomor 10, yang artinya mereka tidak setuju bahwa penggelapan pajak merupakan hal yang etis meskipun orang lain juga melakukannya. Skor tertinggi dari responden pegawai adalah 2,88 pada pertanyaan nomor 6 , yang artinya mereka masih ragu apakah penggelapan pajak adalah etis, jika petugas pajak tidak memiliki moralitas pajak yang baik.

Kelompok responden calon wajib pajak memiliki nilai skor rata-rata 2,56, yang berarti kelompok respondencalon wajib pajak tidak setuju bahwa penggelapan adalah hal yang etis. Skor terendah adalah sebesar 1,82 pada pertanyaan nomor 10, yang artinya mereka tidak setuju bahwa penggelapan pajak adalah hal yang etis meskipun orang lain juga melakukannya. Skor tertinggi dari kelompok responden calon wajib pajak adalah sebesar 2,98 pada pertanyaan nomor 6 , yang berarti mereka masih ragu apakah penggelapan pajak merupakan hal yang etis atau tidak jika petugas pajak tidak memiliki moralitas pajak yang baik.

Responden pegawai memiliki nilai skor rata-rata 2,53, yang berarti kelompok pegawai tidak setuju bahwa penggelapan pajak adalah hal yang etis dengan berbagai alasan. Skor terendah adalah 1,90 pada pertanyaan nomor 10, yang artinya mereka tidak setuju bahwa penggelapan pajak merupakan hal yang etis meskipun orang lain juga melakukannya. Skor tertinggi dari responden 
pegawai adalah 2,93 pada pertanyaan nomor 13, yang artinya mereka masih ragu apakah penggelapan pajak merupakan hal yang etis atau tidak jika pajak digunakan untuk mendukung sebuah perang yang pada akhirnya menimbulkan ketidakadilan.

Responden wirausaha memiliki nilai skor rata-rata 2,58, yang berarti kelompok wirausaha tidak setuju bahwa penggelapan adalah hal yang etis. Skor terendah adalah sebesar 2,00 pada pertanyaan nomor 10 , yang artinya mereka tidak setuju bahwa penggelapan pajak adalah hal yang etis meskipun orang lain juga melakukannya. Skor tertinggi dari responden wirausaha adalah sebesar 2,90 pada pertanyaan nomor 6 , yang berarti mereka masih ragu apakah penggelapan pajak merupakan hal yang etis atau tidak jika petugas pajak tidak memiliki moralitas pajak yang baik.

Responden mahasiswa akuntansi memiliki nilai skor rata-rata 2,21, yang berarti kelompok mahasiswa akuntansi tidak setuju bahwa penggelapan adalah hal yang etis. Skor terendah adalah 1,80 pada pertanyaan nomor 10 , yang artinya mereka tidak setuju bahwa penggelapan pajak adalah hal yang etis meskipun orang lain juga melakukannya. Skor tertinggi dari responden wirausaha adalah 2,60 pada pertanyaan nomor 6 , yang berarti mereka tidak sejutu bahwa penggelapan pajak adalah etis jika petugas pajak tidak memiliki moralitas pajak yang baik.

Responden mahasiswa manajemen memiliki nilai skor rata-rata 2,62, yang berarti kelompok mahasiswa manajemen tidak setuju bahwa penggelapan adalah hal yang etis. Skor terendah adalah 1,83 pada pertanyaan nomor 10, yang artinya mereka tidak setuju bahwa penggelapan pajak adalah hal yang etis meskipun orang lain juga melakukannya. Skor tertinggi dari responden wirausaha adalah 3,37 pada pertanyaan nomor 6 , yang berarti mereka masih ragu apakah penggelapan pajak merupakan hal yang etis atau tidak jika petugas pajak tidak memiliki moralitas pajak yang baik.

Semua responden memiliki nilai skor rata-rata 2,49, yang berarti semua kelompok responden tidak setuju bahwa penggelapan adalah hal yang etis. Skor terendah adalah 1,88 pada pertanyaan nomor 10, yang artinya mereka tidak setuju bahwa penggelapan pajak adalah hal yang etis meskipun orang lain juga melakukannya. Skor tertinggi dari semua responden adalah 2,93 pada pertanyaan nomor 6, yang berarti semua responden masih ragu apakah penggelapan pajak merupakan hal yang etis atau tidak jika petugas pajak tidak memiliki moralitas pajak yang baik.

\subsection{Persepsi Etika Penggelapan Pajak Pada Variabel Sistem Pajak}

Responden kategori pegawai, wirausaha, mahasiswa akuntansi maupun manajemen memiliki kecenderungan distribusi jawaban yang serupa. Dapat dilihat pada grafik dibawah ini, bahwa jawaban keempat kelompok responden sebagian besar ada pada kategori Tidak Setuju, dan paling sedikit ada pada kategori Sangat Setuju.

Persepsi seluruh responden pada variabel sistem perpajakan memiliki nilai skor rata-rata 2,58, yang artinya rata-rata responden tidak setuju dengan tindakan penggelapan pajak walaupun sistem perpajakan tidak berjalan dengan baik. Sistem perpajakan yang dikatakan tidak baik ketika pengelolaan uang pajak yang tidak dapat dipertanggungjawabkan, petugas pajak yang tidak kompeten dan korup, dan juga prosedur perpajakan yang berbelit-belit (Suminarsasi, 2012). Beberapa responden yang diwawancara menyatakan bahwa perilaku penggelapan pajak pada saat 
sistem perpajakan tidak baik tidak akan menyelesaikan masalah bahkan hanya menamabah beban negara saja. Responden juga menyatakan bahwa lebih baik menyelesaikan masalah dengan memberbaiki sistem yang buruk tersebut. Dari pemaparan para responden tersebut dapat dimaknai bahwa sebenarnya masyarakat masih peduli terhadap pentingnya pajak dalam membangun sebuah negara. Responden tidak setuju dengan penggelapan pajak sebagai hal yang etis karena dengan pemikiran bahwa pajak adalah kewajiban wajib pajak. Dari empat kategori responden, kelompok pegawai dan mahasiswa akuntansi memiliki rata-rata skor masing-masing 2,57 dan 2,31 yang artinya kelompok ini tidak setuju dengan adanya penggelapan pajak walaupun tidak ada sistem perpajakan yang baik. Sedangkan kelompok wirausaha dan mahasiswa manajemen memiliki rata-rata skor masing-masing 2,63 dan 2,79 yang artinya mereka masih ragu dengan apakah penggelapan pajak merupakan hal yang etis ataukah tidak etis, meskipun negara tidak memiliki sistem perpajakan yang baik. Keraguan kelompok tersebut dapat saja disebabkan oleh persepsi bahwa jika sistem berjalan dengan tidak baik, maka ada kecenderungan terjadi korupsi atas pendapatan pajak yang telah mereka bayar sehingga mereka tidak dapat merasakan haknya sebagai wajib pajak (Suminarsasi, 2012).

\section{Gambar 2}

Distribusi Jawaban Responden Pada Variabel Sistem Perpajakan (\%)

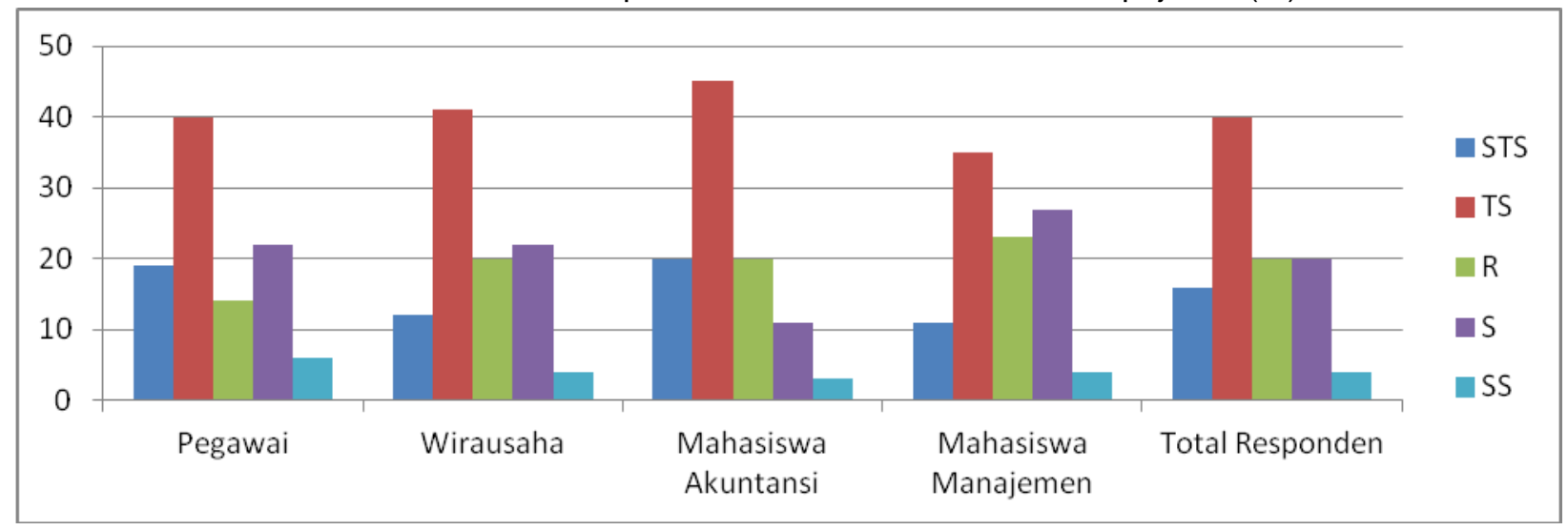

Sumber: Data primer diolah, 2015

Kelompok responden wajib pajak maupun calon wajib pajak memiliki kecenderungan distribusi jawaban yang serupa. Dapat dilihat pada grafik dibawah ini, jawaban responden sebagian besar ada pada kategori tidak setuju, dan paling sedikit ada pada kategori sangat setuju.

Dari grafik pada Gambar 3 memang tampak bahwa sebagian besar dari kelompok responden menjawab tidak setuju dengan tindakan penggelapan pajak. Kelompok responden wajib pajak dan calon wajib pajak, maka masing-masing memiliki rata-rata skor 2,60 dan 2,55. Hal ini berarti bahwa wajib pajak maupun calon wajib pajak sama-sama tidak setuju dengan adanya tindakan penggelapan pajak walaupun negara tidak memiliki sistem perpajakan yang baik. 
Gambar 3

Distribusi Jawaban Responden Pada Variabel Sistem Perpajakan (\%)

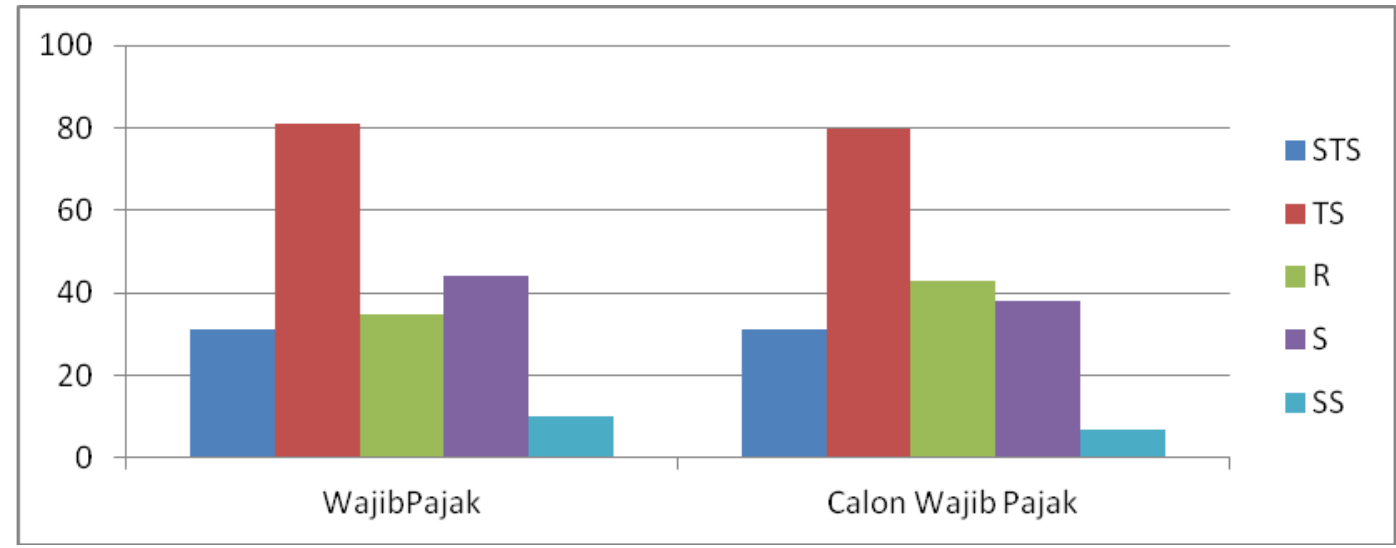

Sumber: Data primer diolah, 2015

\subsection{Persepsi Etika Penggelapan Pajak Pada Variabel Keadilan Pajak}

Responden kategori pegawai, wirausaha, mahasiswa akuntansi maupun manajemen memiliki kecenderungan distribusi jawaban yang serupa. Dapat dilihat pada grafik di bawah ini, bahwa jawaban keempat kelompok responden sebagian besar ada pada kategori Tidak Setuju, dan paling sedikit ada pada kategori Sangat Setuju.

Gambar 4

Distribusi Jawaban Responden Pada Variabel Keadilan Perpajakan (\%)

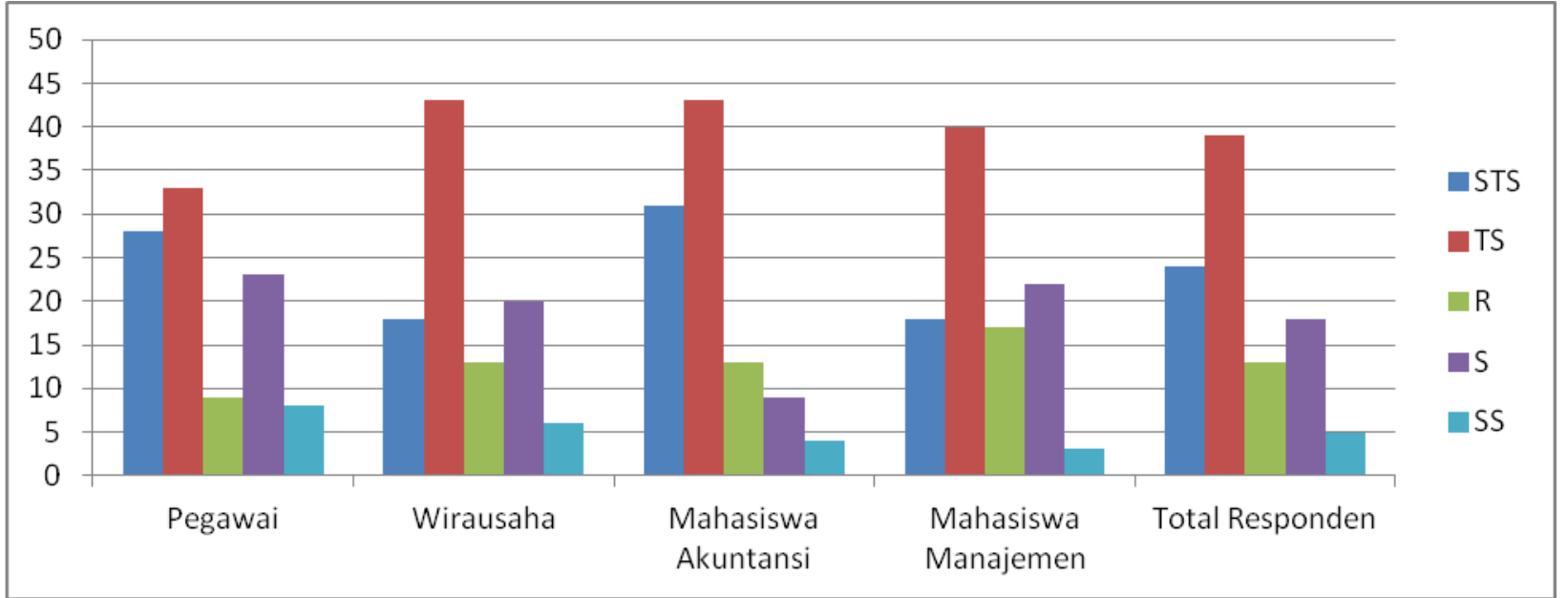

Sumber: Data primer diolah, 2015

Persepsi seluruh responden pada variabel keadilan perpajakan memiliki nilai skor rata-rata adalah 2,42, yang artinya rata-rata responden tidak setuju dengan tindakan penggelapan pajak walaupun keadilan dalam perpajakan tidak berjalan dengan baik. Dikatakan tidak adanya keadilan dalam perpajakan ketika wajib pajak harus membayar pajak tidak sejalan dengan manfaat yang dinikmatinya dari pemerintah, wajib pajak membayar kewajiban pajaknya tidak sesuai dengan dasar kemampuan membayar, beban pajaknya sama atas semua wajib pajak yang memperoleh penghasilan yang sama dengan jumlah tanggungan yang sama namun membedakan jenis penghasilan atau sumber penghasilan. Dari hasil wawancara, responden menyatakan bahwa mereka akan patuh terhadap peraturan yang ada. Jika terjadi ketidakadilan dalam perpajakan, maka yang harus diubah adalah aturan perpajakan agar adil, karena jika dengan menggelapkan pajak hanya 
akan membuat negara menjadi rugi. Dari empat kategori responden memiliki skor masing-masing pegawai 2,51, wirausaha 2,55, mahasiswa akuntansi 2,12 dan mahasiswa manajemen 2,51 yang artinya seluruh kelompok tidak setuju dengan adanya penggelapan pajak walaupun tidak ada keadilan dalam perpajakan. Apabila dilakukan pengelompokan berdasarkan kategori wajib pajak dan calon wajib pajak, maka masing-masing memiliki rata-rata skor 2,53 dan 2,31. Hal ini berarti bahwa wajib pajak maupun calon wajib pajak sama-sama tidak setuju bahwa tindakan penggelapan pajak adalah hal yang etis walaupun tidak ada keadilan dalam perpajakan. Dari hasil wawancara, responden menyatakan bahwa mereka menjadikan agama sebagai patokan sesorang dalam memaknai persepsi penggelapan pajak adalah hal yang tidak etis.

Kelompok responden wajib pajak maupun calon wajib pajak memiliki kecenderungan distribusi jawaban yang serupa. Dapat dilihat pada grafik dibawah ini, bahwa jawaban keempat kelompok responden sebagian besar ada pada kategori tidak setuju, dan paling sedikit ada pada kategori sangat setuju.

Gambar 5

Distribusi Jawaban Responden Pada Variabel Keadilan Perpajakan (\%)

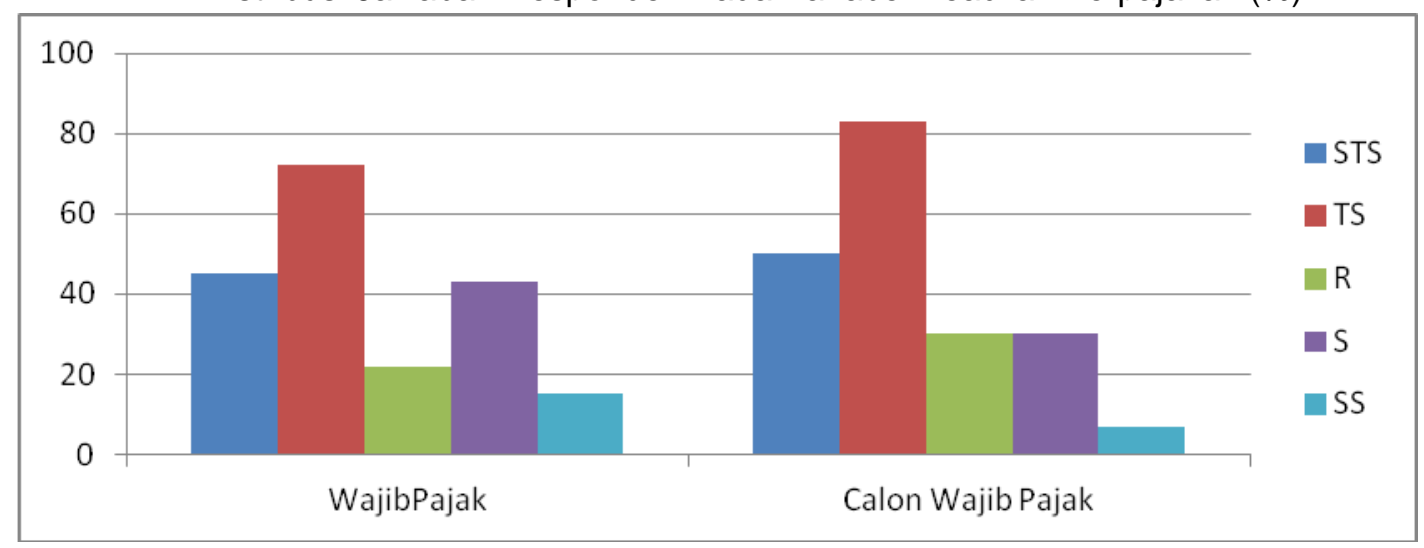

Sumber: Data primer diolah, 2015

Persepsi seluruh responden pada variabel keadilan perpajakan memiliki nilai skor rata-rata adalah 2,42 , yang artinya rata-rata responden tidak setuju dengan tindakan penggelapan pajak walaupun keadilan dalam perpajakan tidak berjalan dengan baik. Dikatakan tidak adanya keadilan dalam perpajakan ketika wajib pajak harus membayar pajak tidak sejalan dengan manfaat yang dinikmatinya dari pemerintah, wajib pajak membayar kewajiban pajaknya tidak sesuai dengan dasar kemampuan membayar, beban pajaknya sama atas semua wajib pajak yang memperoleh penghasilan yang sama dengan jumlah tanggungan yang sama namun membedakan jenis penghasilan atau sumber penghasilan.

Dari grafik diatas memang tampak bahwa sebagian besar dari kelompok responden menjawab tidak setuju dengan tindakan penggelapan pajak. Kelompok responden wajib pajak dan calon wajib pajak masing-masing memiliki rata-rata skor 2,53 dan 2,31. Hal ini berarti bahwa wajib pajak maupun calon wajib pajak sama-sama tidak setuju bahwa tindakan penggelapan pajak adalah hal yang etis walaupun tidak ada keadilan dalam perpajakan. 


\subsection{Persepsi Etika Penggelapan Pajak Pada Variabel Diskriminasi}

Responden kategori pegawai, wirausaha, mahasiswa akuntansi maupun manajemen memiliki kecenderungan distribusi jawaban yang serupa. Dapat dilihat pada grafik dibawah ini, bahwa jawaban keempat kelompok responden sebagian besar ada pada kategori Tidak Setuju, dan paling sedikit ada pada kategori Sangat Setuju.

Gambar 6

Distribusi Jawaban Responden Pada Variabel Diskriminasi (\%)

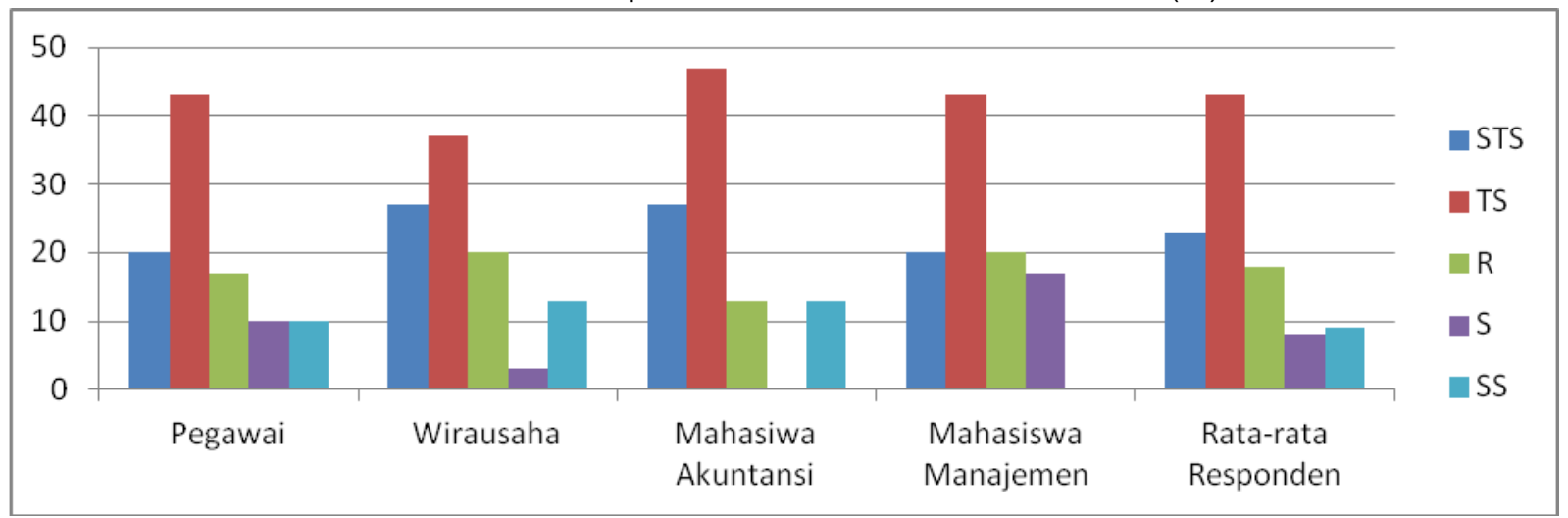

Sumber: Data primer diolah, 2015

Persepsi seluruh responden pada variabel keadilan perpajakan memiliki nilai skor rata-rata adalah 2,37, yang artinya rata-rata responden tidak setuju dengan tindakan penggelapan pajak walaupun ada diskriminasi dalam perpajakan. Diskriminasi dalam perpajakan adalah ketika pemerintah memberikan pelayanan perpajakan dengan tidak seimbang antar kelompok masyarakat (kelompok ras, agama dan lainnya). Dari empat kategori responden memiliki skor masing-masing pegawai 2,47, wirausaha 2,40, mahasiswa akuntansi 2,27 dan mahasiswa manajemen 2,33 yang artinya seluruh kelompok tidak setuju dengan adanya penggelapan pajak walaupun ada diskrimiasi dalam perpajakan.

Kelompok responden wajib pajak maupun calon wajib pajak memiliki kecenderungan distribusi jawaban yang serupa. Dapat dilihat pada grafik dibawah ini, bahwa jawaban keempat kelompok responden sebagian besar ada pada kategori tidak setuju, dan paling sedikit ada pada kategori sangat setuju.

Gambar 7

Distribusi Jawaban Responden Pada Variabel Diskriminasi (\%)

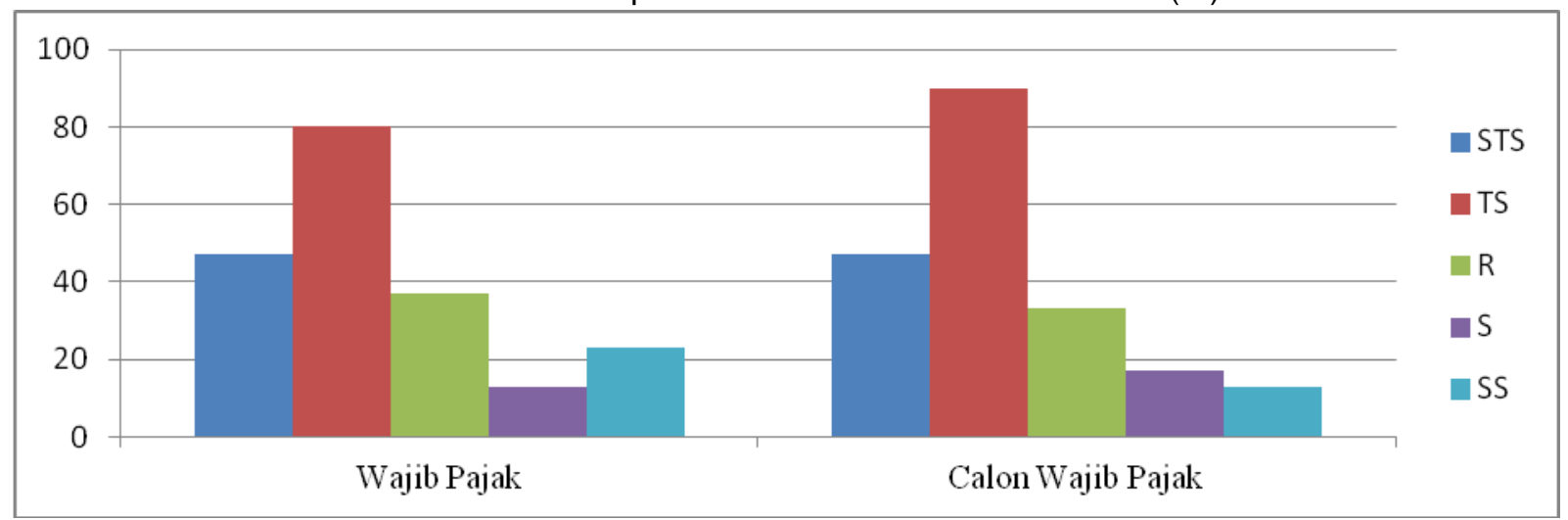

Sumber: Data primer diolah, 2015 
Persepsi seluruh responden pada variabel keadilan perpajakan memiliki nilai skor rata-rata 2,37, yang artinya rata-rata responden tidak setuju dengan tindakan penggelapan pajak walaupun ada diskriminasi dalam perpajakan. Diskriminasi dalam perpajakan adalah ketika pemerintah memberikan pelayanan perpajakan dengan tidak seimbang antar kelompok masyarakat (kelompok ras, agama dan lainnya).

Dari grafik diatas memang tampak bahwa sebagian besar dari kelompok responden menjawab tidak setuju dengan tindakan penggelapan pajak. Apabila dilakukan pengelompokan berdasarkan kategori wajib pajak dan calon wajib pajak, maka masing-masing memiliki rata-rata skor 2,43 dan 2,30. Hal ini berarti bahwa wajib pajak maupun calon wajib pajak sama-sama tidak setuju dengan adanya tindakan penggelapan pajak walaupun ada diskriminasi dalam perpajakan.

\section{Simpulan, Implikasi, Keterbatasan dan Saran}

\subsection{Simpulan dan Implikasi}

Berdasarkan hasil analisis dan pembahasan dapat ditarik beberapa simpulan sebagai berikut:

1. Rata-rata responden tidak setuju bahwa tindakan penggelapan pajak adalah hal yang etis walaupun sistem perpajakan berjalan dengan tidak baik.

2. Rata-rata responden juga tidak setuju bahwa tindakan penggelapan pajak adalah hal yang etis walaupun terdapat ketidakadilan dalam perpajakan

3. Sekalipun terdapat diskriminasi dalam perpajakan, rata-rata responden tetap tidak setuju bahwa tindakan penggelapan pajak adalah hal yang etis.

Hasil penelitian ini memberikan gambaran bahwa wajib pajak dan calon wajib pajak telah memberikan respon persepsi yang positif terhadap etika penggelapan pajak di Indonesia. Wajib pajak dan calon wajib pajak menganggap bahwa penggelapan pajak adalah hal yang tidak etis. Hal ini mengindikasikan adanya persepsi yang baik, bahwa masyarakat memiliki pandangan positif terhadap pajak. Hal ini dapat menjadi modalbagi pemerintah dalam rangka memperbaiki atau meningkatkan pendapatan negara melalui penerimaan pajak. Perspesi dari responden ini dapat dijadikan masukan untuk pemerintah dalam rangkamendesain pembinaan kepada masyarakat agar masyarakat lebih patuh lagi membayar pajak.

\subsection{Keterbatasan dan Saran}

Hal yang menjadi keterbatasan dalam melakukan penelitian ini pada saat menyebarkan kuesioner adalah peneliti tidak menemukan kelompok kategori pekerja bebas (dokter, notaris, dan sebagainya) yang dapat dijadikan responden dalam penelitian ini.Oleh sebab itu, maka peneliti menyarankan untuk penelitian selanjutnya dapat menambahkan kategori pekerja bebas (dokter, notaris dan sebagainya). Karena karakteristik dari kategori pekerja bebas adalah mereka mempekerjakan diri mereka sendiri dengan menggunakan ilmu yang mereka telah pelajari sebelumnya, sehingga dapat memperluas cakupan responden. Sebaiknya penelitian selanjutnya 
tidak hanya sebatas wilyah Salatiga agar dapat membandingkan persepsi etika penggelapan pajak

lebih dari satu universitas.

\section{Daftar Pustaka}

Azwar, S. 2002. Sikap Manusia: Sikap dan Pengukurannya. Yogyakarta : Pustaka Pelajar.

Danandjaja, J. 2003. Diskriminasi Terhadap Minoritas Masih Merupakan Masalah Aktual di Indonesia Sehingga Perlu Ditanggulangi Segera. http://www.lfip.org/. (Diakses 30 Januari 2015).

Direktorat Jendral Pajak. 2011. Surat Edaran Direktur Jendral Pajak SE - 98/PJ/2011. http://www.ortax.org/ortax/?mod=aturan\&page=show\&id=14907 (Diakses 30 Januari 2015).

Direktorat Jendral Pajak. 2014. Peran Pajak Terhadap Pembangunan Nasional dan Daerah. http://www.pajak.go.id/node/9975?lang=en (Diakses 30 Januari 2015).

Gera, Iris. 2013. BPK: Penerimaan Pajak Tidak Capai Target dalam 4 Tahun Terakhir. http://www.voaindonesia.com/content/bpk-penerimaan-pajak-tidak-capai-target-dalam-4-tahunterakhir/1683033.html (Diakses 10 Desember 2014).

Gozhali, I. 2005. Aplikasi Analisis Multivariate dengan Program SPSS. Edisi Ketiga. Semarang: Badan Penerbit Universitas Diponegoro.

Hukumonline.com. 2013. Lima Modus Kejahatan Perpajakan http://www.hukumonline.com/berita/baca/lt51c7fa3cc5d4c/lima-modus-kejahatan-perpajakan (Diakses 30 Januari 2015).

Ika. 2012. Kepala KPP Wonosari Raih Doktor Usai Teliti Penggelapan Pajak. http://www.ugm.ac.id/index.php?page=rilis\&artikel=4561 (Diakses 3 Desember 2014).

Kompas.com. 2013. Penggelapan Pajak Masif. http://perpustakaan.bappenas.go.id (Diakses 30 Januari 2015).

Maftuchan, A., dan W. Saputra. 2014. Evaluasi Realisasi Penerimaan Pajak 2013: Berada Pada Titik Terendah Sejak 2011. http://theprakarsa.org/new/in/papers/detail/9/Evaluasi-RealisasiPenerimaan-Pajak-2013-Berada-pada-Titik-Terendah-sejak-2011 (Diakses 30 Januari 2015).

Mardiasmo. 2004. Akuntansi Sektor Publik. Yogyakarta: Andi.

Mardiasmo. 2009. Perpajakan: Edisi Revisi 2009. Yogyakarta: Andi.

Prasetyo, S. 2010. Persepsi Etis Penggelapan Pajak Bagi Wajib Pajak Di Wilayah Surakarta. Tesis. Surakarta: Universitas Sebelas Maret Surakarta.

Rahayu, S.K. 2010. Perpajakan Indonesia. Yogyakarta: Graha IImu.

Rahman, I. S. 2013. Pengaruh Keadilan, Sistem Perpajakan, Diskriminasi, dan Kemungkinan Terdeteksi Kecurangan Terhadap Persepsi Wajib Pajak Mengenai Etika Penggelapan Pajak (Tax Evasion). Skripsi. Jakarta: Universitas Islam Negeri Syarif Hidayatullah.

Rachmadi, W. 2014. Faktor-Faktor Yang Mempengaruhi Persepsi Wajib Pajak Orang Pribadi Atas Perilaku Penggelapan Pajak. Semarang: Universitas Diponegoro Semarang.

Reskino, Rini, dan D. Novitasari. 2013. Persepsi Mahasiswa Akuntansi Mengenai Penggelapan Pajak. Makalah disajikan dalam Simposium Nasional Perpajakan IV. Bangkalan.

Sekaran, U. 2006. Research Methods for Bussiness. Buku 2 Edisi 4. Jakarta: Salemba Empat.

Siahaan, M. P. 2010. Hukum Pajak Material. Yogyakarta: Graha IImu.

Sigit, T.H. 2012. Etika Bisnis Modern: Pendekatan Pemangku Kepentingan. Yogyakarta: UPP STIM YKPN.

Sugiyono. 2013. Metode Penelitian Manajemen. Bandung: Alfabeta.

Sugiyono. 2014. Metode Penelitian Kuantitatif, Kualitatif, dan R\&D. Bandung: Alfabeta.

Suminarsasi, W., dan Supriyadi. 2012. Pengaruh Keadilan, Sistem Perpajakan, dan Diskriminasi Terhadap Persepsi Wajib Pajak Mengenai Etika Penggelapan Pajak (Tax Evasion) http://asp.trunojoyo.ac.id/wp-content/uploads/2014/03/086-PPJK-15.pdf (Diakses 10 Februari 2015)

Surwono, S. 1999. Psikologi Sosial: Individu dan Teori-Teori Psikologi Sosial. Jakarta: Balai Pustaka.

Untung, H. B. 2012. Hukum dan Etika Bisnis. Yogyakarta: Andi.

Waluyo. 2013. Perpajakan Indonesia. Edisi 11. Jakarta: Salemba Empat.

Wicaksono, K. A. 2014. Etika Penggelapan Pajak (tax evasion): Perbedaan Persepsi Mahasiswa Ekonomi, Hukum, dan Psikologi. Skripsi. Yogyakarta: Universitas Gadjah Mada.

Yetmi, Y., dan R. Yulistia. 2014. Faktor - Faktor Yang Mempengaruhi Persepsi Wajib Pajak Mengenai Penggelapan Pajak. E-Journal Universitas Bung Hatta 5(1). 